\title{
IMPROVING COMPETITIVE POWER PRODUCTS BY STRATEGIC ENVIRONMENTAL ANALYSIS: CASE STUDY CREDITS PRODUCTS' EMPLOYEES OF BANK BPR
}

\author{
Kunto Ajibroto \\ Politeknik Pajajaran ICB Bandung \\ Email: kuntoajibrata@gmail.com \\ Dematria Pringgabayu \\ Politeknik Pajajaran ICB Bandung \\ Email: dematria.pringgabayu@ poljan.ac.id
}

\begin{abstract}
Strategic environment analysis is part of strategic planning component and is a process to always put the company in a strategic position, so that in its development will always be in a favorable position. By analyzing external factors and internal factors, it will be possible to find out the most appropriate strategy formulation for BPR Bhakti Daya Ekonomi in facing the increasingly fierce competition. The research method used is qualitative with data collection using interview and observation, while for data analysis using SWOT method which also use analysis of EFAS and IFAS. The results of this study indicate that the position of BPR Bhakti Daya Ekonomi for Credit Employees products is located in quadrant IV. In this quadrant the bank is in a position where its internal advantage is relatively more dominant than its weakness. However, in the face of the threat environment is relatively greater than the chances. This means that the bank has a relatively better internal capability to expand its business, especially by utilizing some of its internal strengths.
\end{abstract}

Keywords: SWOT, Competitive Strategy, Banking Industry 


\section{PENDAHULUAN}

Peraturan yang ditetapkan oleh pemerintah tentang perbankan membatasi ruang gerak Bank Perkreditan rakyat dengan adanya larangan-larangan dalam kegiatan usahanya seperti yang tercantum pada pasal 13 Undang-undang pokok perbankan yang menyebutkan bahwa Bank Perkreditan Rakyat dilarang untuk : (a) Menerima simpanan berupa giro dan ikut serta dalam lalu lintas pembayaran (b) Melakukan kegiatan usaha dalam valuta asing (c) Melakukan penyertaan modal (d) Melakukan usaha perasuransian (e)Melakukan usaha lain diluar kegiatan usaha sebagaimana dimaksudkan dalam pasal 13. Sedangkan kegiatan yang diperbolehkan adalah (a) Menghimpun dana dari masyarakat dalam bentuk simpanan deposito berjangka, tabungan, dan/atau bentuk lainnya yang dipersamakan dengan itu (b) Memberikan kredit (c)Menyediakan pembiayaan bagi nasabah berdasarkan prinsip bagi hasil sesuai dengan ketentuan yang ditetapkan dalam peraturan pemerintah (d) Menempatkan dananya dalam bentuk Sertifikat Bank Indonesia (SBI) deposito berjangka, sertifikat deposito, dan/atau tabungan pada bank lain.

Ruang gerak yang terbatas ini membuat BPR sulit untuk menembus segmen pasar bank umum, akan tetapi sebaliknya dengan melihat kecilnya resiko yang ada pada BPR dalam pengucuran kredit (jumlah pinjaman yang dikaitkan dengan agunannya) dan dalam penghimpunan dana yang juga relatif kecil dimana selama ini menjadi pangsa pasar BPR sudah mulai dilirik oleh bank-bank umum, ini sebuah ancaman yang serius bagi BPR. Memang sampai saat ini regulasi dari pemerintah yang mengatur ruang gerak (akses) bank umum untuk masuk kewilayah pedesaan belum ada, disinilah celah yang dimanfaatkan oleh bank-bank umum untuk memperluas jaringannya dengan membuka kantor-kantor kasnya. Sementara BPR terus bertahan dengan segala keterbatasannya.

Berdasarkan sumber data yang ada pada Bank Indonesia sampai dengan tahun 2014, di Daerah Istimewa Yogyakarta (DIY) saja sudah ada 9 buah Kantor Cabang Bank Pemerintah (BUMN), 19 Kantor Cabang bank Umum Swasta, 65 Bank Perkreditan Rakyat (BPR) , 101 Unit Bank Rakyat Indonesia (BRI) , 147 buah Bank Kredit Desa (BKD) serta 9 buah Badan Usaha Kredit Pedesaan 
(BUKP) dan ini merupakan tantangan yang cukup berat untuk bisa memperebutkan porsi "kue" yang tersisa.

Persaingan yang sangat ketat ini membuat BPR khususnya di Yogyakarta harus membuat dan menyusun strategi yang tepat, perang suku bunga sudah bukan hal yang tabu dan aneh bagi sebuah bank, strategi pembagian hadiah juga kian marak dan menjamur atau strategi layanan jemput bola juga merupakan “trik" yang sering dilakukan guna menarik nasabah. Perang "kemampuan" yang tidak seimbang dibisnis retail banking inilah yang menyebabkan pangsa pasar BPR semakin kecil. Melihat kondisi tersebut BPR mau tidak mau harus segera membangun dan mengembangkan startegi pemasaran yang tepat untuk dapat mempertahankan dan mengembangkan segmen pasarnya.

Perebutan pasar dengan bank umum yang belakangan ini marak diantaranya adalah pada produk kredit, khususnya kredit yang diberikan kepada Pegawai Negeri Sipil, TNI dan Polri atau sering disebut Kredit Pegawai. Produk kredit ini kecil resikonya karena angsuran tiap bulannya menggunakan sistim pemotongan gaji dengan nominal pinjaman yang relatif tidak terlalu besar, yang sementara ini sebagian besar diberikan oleh BPR dan sebagian oleh bank umum milik pemerintah.

Kredit Pegawai bagi BPR. Bhakti Daya Ekonomi mempunyai arti yang amat penting, karena Kredit Pegawai ini merupakan penyumbang terbesar pada pendapatan perusahaan, dari data yang ada pada bulan Desember 2002 tercatat Out Standing Credit (OSC) 75,61\% dikuasai oleh Kredit Pegawai ini, demikian juga jumlah nasabahnya yang berjumlah $75,09 \%$ dari total jumlah nasabah BPR. Bhakti Daya Ekonomi yang berjumlah 7.412 dengan tingkat ketidak lancaran pengembalian kreditnya hanya $0,28 \%$. Peluang inilah yang agaknya mulai diincar oleh bank umum yang secara otomatis menjadi ancaman bagi para Bank Perkreditan Rakyat, khususnya BPR. Bhakti Daya Ekonomi .

Untuk lebih jelasnya penulis sajikan data yang menggambarkan posisi Kredit Pegawai di BPR. Bhakti Daya Ekonomi pada bulan Desember 2015. 
Tabel 1 Out Standing Credit, Pendapatan dan Jumlah Nasabah

\begin{tabular}{|c|c|c|c|c|c|}
\hline \multirow[t]{2}{*}{ PRODUK KREDIT } & \multicolumn{2}{|c|}{$\begin{array}{c}\text { OUT STANDING } \\
\text { CREDIT }\end{array}$} & \multirow{2}{*}{$\begin{array}{c}\text { PENDAPAT } \\
\text { AN } \\
\text { AKHIR } \\
\text { TAHUN }\end{array}$} & \multicolumn{2}{|c|}{ NASABAH } \\
\hline & JUMLAH & $\%$ & & JUMLAH & $\%$ \\
\hline Kredit Pegawai & $\begin{array}{r}22,188,411,05 \\
0\end{array}$ & 75.61 & $563,573,500$ & 5,566 & 75.09 \\
\hline Kredit Lansia & $1,088,645,550$ & 3.71 & $27,875,375$ & 352 & 4.75 \\
\hline Kredit Umum & $3,638,884,770$ & 12.40 & $69,339,410$ & 626 & 8.45 \\
\hline Kredit Usaha & $120,047,350$ & 0.41 & $5,192,350$ & 453 & 6.11 \\
\hline Kredit Swadaya Masy. & $1,333,348,275$ & 4.54 & $27,412,155$ & 158 & 2.13 \\
\hline $\begin{array}{l}\text { Kredit Pengusaha } \\
\text { Mikro }\end{array}$ & $975,847,600$ & 3.33 & $20,513,750$ & 257 & 3.47 \\
\hline Jumlah OSC & $\begin{array}{r}29,345,184,59 \\
5\end{array}$ & 100.00 & $713,906,540$ & 7,412 & 100.00 \\
\hline
\end{tabular}

Sumber: Laporan Bulan Desember 2015

Dari tabel diatas dapat diketahui bahwa posisi kredit pegawai merupakan penyumbang yang paling dominan dari total produk kredit BPR Bhakti Daya ekonomi dengan total pendapatan sebesar Rp. 563.573.500 atau 75,09\% dari seluruh total produk kredit sebesar Rp. 713.906.540 dengan jumlah kredit yang dikucurkan sebesar Rp. 22.188.411.050. Dilihat dari kinerja kredit pegawai menunjukkan bahwa 99,69 \% atau Rp. 22.357.621,100 adalah kredit pegawai dengan klasifikasi lancar, kurang lancar sebesar Rp. 38.528 .500 (0,17\%), dan diragukan sebesar Rp. 30.291 .950 (0,14\%). Memasuki periode tahun 2003 dan yang akan datang BPR Bhakti Daya Ekonomi akan memasuki persaingan yang semakin ketat dengan dibukannya kantor Cabang BPD ditambah lagi dengan keseriusan BRI dalam menggarap bisnis perbankan ritel dengan segala kecanggihan sistem informasi, dan sumber daya manusia yang mereka miliki. Dengan adanya arus perbankan berpindah ke sektor ritel menyebabkan persaingan menjadi lebih keras dan bersifat global. Agar tetap bisa eksis dan mampu bersaing khususnya dalam hal penyaluran kredit pegawai, maka BPR Bhakti Daya Ekonomi harus menyusun formulasi strategi yang sesuai dengan kondisi lingkungan internal maupun kondisi lingkungan eksternalnya agar mampu bersaing dengan para kompetitornya. Berdasarkan uraian tersebut maka penulis 
tertarik untuk melakukan penelitian tentang lingkungan eksternal dan lingkungan internal BPR Bhakti Daya Ekonomi dengan analisis swot sebagai dasar penyusunan formulasi strategi dalam menghadapi persaingan yang semakin ketat khususnya dari Bank Pembangunan Daerah (BPR) dan Bank Rakyat Indonesia (BRI) yang berada di wilayah kecamatan Pakem Kabupaten Sleman.

\section{TINJAUAN LITERATUR}

\section{Konsep Strategi}

Porter (2008) menjelaskan bahwa strategi merupakan hal unik dan posisinya bernilai, melibatkan seperangkat kegiatan yang berbeda. Ketika kita telah memberikan atau menawarkan hal dengan cara yang berbeda dari apa yang pernah kita lakukan sebelumnya, maka hal itu disebut strategi. Strategi juga dapat dikatakan sebagai inti dari manajemen secara umum yang meliputi menjabarkan posisi perusahaan, membuat beberapa tarikan dan menempa setiap kegiatan dengan tepat. Strategi juga diartikan sebagai penciptaan timbal balik dalam kompetisi, mengombinasikan aktivitas, serta menciptakan kesesuaian antaraktivitas yang dilakukan oleh perusahaan

Keberhasilan perusahaan dalam mencapai tujuannya tergantung pada keberhasilan orang-orang dalam perusahaan mengimplementasikan strategi baik pada tingkat koorporat, fungsional maupun pada tingkat operasional. Pfeffer (2003) mengemukakan bahwa keberhasilan perusahaan itu datang dari proses penghantar nilai (delivering value) kepada customer dan dari konsepsi bagaimana mengorganisasikan dan mengelola orang-orang untuk mewujudkan tujuan perusahaan. Di sini timbul masalah yaitu, tidak semua sumber daya manusia yang ada dalam perusahaan memahami proses itu. Harus dipahami bahwa misi dan tujuan yang diemban perusahaan adalah dalam konteks memenuhi kebutuhan customers dan bukan hanya kebutuhan perusahaan.

Menurut Rangkuti (2002), ada dua konsep strategi untuk mencapai tujuan yaitu :

1. Distinctive Competitive 
Yaitu suatu perusahaan yang mempunyai kekuatan yang tidak mudah ditiru dan lebih baik dari perusahaan pesaing, dan kemampuan spesifik perusahaanpersh ini sangat tergantung kepada :

1. Keahlian tenaga kerja.

2. Kemampuan sumber daya yang ada.

Dua faktor tersebut menyebabkan perusahaan dapat lebih unggul dibandingkan pesaingnya. Keahlian sumber daya manusia yang lebih tinggi muncul dari kemampuan membentuk fungsi khusus yang lebih efektif dibandingkan dengan pesaingnya.

\section{Competitive Advantage}

Yaitu suatu kegiatan spesisfik yang dikembangkan oleh perusahaan agar lebih unggul dibandingkan dengan pesaingnya, untuk itu diperlukan suatu perencanaan strategis yang benar-benar matang dan cermat

Lingkungan perusahaan bukan hanya telah makin bergejolak dalam tahuntahun belakangan ini tapi juga saling berhubungan secara lebih erat. Dengan semakin ketatnya persaingan di bisnis perbankan akhir-akhir ini telah banyak memunculkan perubahan sistem tak terkecuali pada BPR Bhakti Daya Ekonomi. Dinamika tersebut memerlukan tanggapan yang serius dari perusahaan. Pertama, perusahaan harus berfikir strategis, yang jarang dilakukan sebelumnya. Kedua, perusahaan harus menterjemahkan inputnya untuk strategi yang lebih efektif guna menanggulangi lingkungannya yang telah berubah. Ketiga, perusahaan harus mengembangkan alasan yang diperlukan untuk meletakkan landasan bagi pemakaian dan pelaksanaan strateginya

\section{Strategi Bersaing}

Setiap perusahaan yang bersaing dalam suatu industri mempunyai strategi bersaing yang dikembangkan melalui proses perencanaan atau mungkin telah dikembangkan melalui kegiatan-kegiatan dari berbagai departemen fungsionalnya. Menurut Porter (2008) strategi bersaing adalah merupakan kombinasi tujuan yang diperjuangkan oleh perusahaan dengan suatu alat dimana perusahaan berusaha untuk mencapai kesana. Untuk merumuskan strategi bersaing masih menurut 
Porter harus mempertimbangkan 4 (empat) faktor utama yang menentukan batasbatas yang dapat dicapai oleh perusahaan sebagaimana dalam bagan berikut

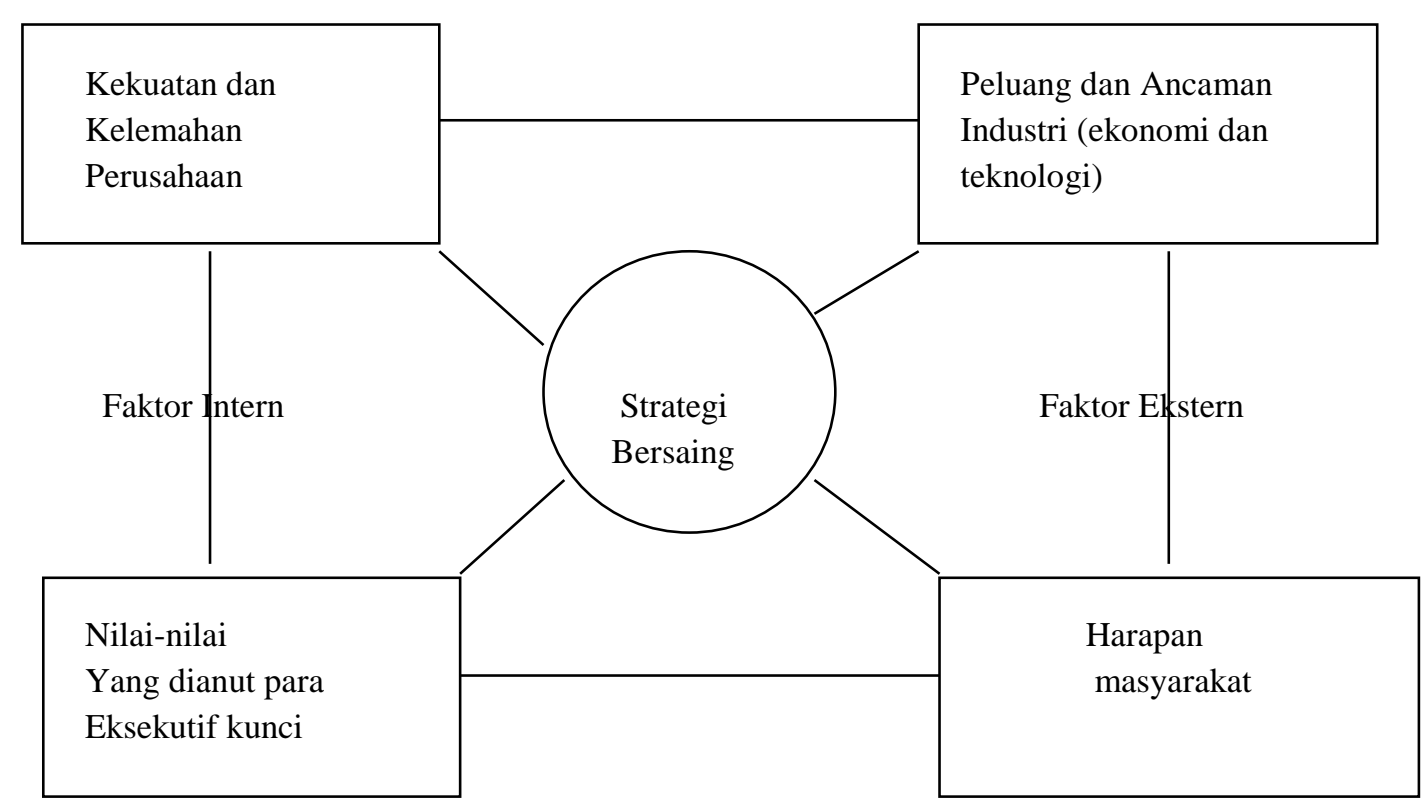

\section{Gambar 1. Konteks Perumusan Strategi Bersaing} (Porter, 2008)

Dengan demikian pokok perumusan adalah menghubungkan perusahaan dengan lingkungannya baik sosial, kekuatan ekonomi maupun pesaing itu sendiri, dimana kuncinya terletak pada kemampuan perusahaan untuk menanggulanginya. Tujuan strategi bersaing adalah untuk menemukan posisi perusahaan tersebut dimana perusahaan dapat melindungi diri dengan sebaik-baiknya terhadap tekanan persaingan atau dapat mempengaruhi tekanan tersebut secara positif. Kekuatan gaya persaingan dalam suatu industri menentukan tingkat pengembalian menuju tingkat pasar bebas dengan demikian juga mengendalikan kemampuan perusahaan untuk mempertahankan tingkat pengembalian yang diatas rata-rata.

Menurut Porter (2008) ada 5 (lima) kekuatan persaingan yang mencerminkan kenyataan bahwa persaingan dalam suatu industri yaitu :

1. Ancaman masuknya pendatang baru yang potensial.

2. Ancaman produk atau jasa pengganti.

3. Kekuatan tawar menawar pembeli. 
4. Kekuatan tawar menawar pemasok (supplier).

5. Persaingan diantara para pesaing yang ada.

Kelima kekuatan persaingan diatas secara bersama-sama menentukan intensitas persaingan dan kemampulabaan dalam industri dan kekuatan-kekuatan yang paling besar akan menentukan serta menjadi sangat penting bila dipandang dari sudut perumusan strategi.

\section{Analisis SWOT}

Analisis SWOT (Strength Weaknes Opportunity Threat) me-rupakan analisis yang digunakan untuk mengetahui seberapa besar faktor-faktor intern dan ekstern akan mempengaruhi perusahaan. Pendekatan ini merupakan evaluasi untuk mengubah faktor negatif baik yang berasal dari kelemahan (weaknesses) perusahaan dan ancaman (threat) pasar menjadi faktor-faktor positif yang berupa kekuatan (strength) dan peluang dari faktor eksternal (opportunities). (Thompson \& Strickland, 2007: 117).

Analisis SWOT berpedoman pada konsep dasar bahwa terdapat dua faktor pengaruh terhadap keberhasilan perusahaan. Singh \& Kohli (2006) memaparkan faktor pengaruh yang pertama merupakan faktor yang dalam kendali manajemen karena itu harus disiasati untuk diptimalkan/dimaksimumkan keunggulan dan diminimumkan kelemahan. Faktor yang kedua merupakan faktor di luar kendali manajemen yang dicoba untuk dieskploitasi (peluang) dan dieleminir (ancaman).

David (2011) menjelaskan analisis lingkungan strategis merupakan bagian dari komponen perencanaan strategis dan merupakan suatu proses untuk selalu menempatkan perusahaan pada posisi strategis, sehingga didalam perkembangannya akan selalu berada pada posisi yang menguntungkan. Lingkup analisis lingkungan strategis meliputi analisis lingkungan internal dan analisis lingkungan eksternal.

1. Analisis lingkungan internal Analisis lingkungan internal pada dasarnya adalah proses identifikasi yang mengurai menjadi kekuatan dan kelemahan yang mencakup perusahaan, sumber daya manusia, pembiayaan, efektivitas dan efisiensi, 
sarana dan prasarana, dan lain-lain yang memiliki pengaruh terhadap pembuatan kebijakan/keputusan perusahaan. Analisis lingkungan internal pada dasarnya mencakup dua aspek, yaitu kekuatan (strength) dan kelemahan (weakness).

- Strength / kekuatan

Merupakan kekuatan yang dimiliki oleh perusahaan biasanya disini berujud sumber daya yang dimiliki oleh perusahaan baik sumber daya manusia maupun sumber daya lainnya. Termasuk didalamnya : tenaga kerja, goodwill, modal, mesin dan sebagainya..

- Weakness / kelemahan

Merupakan kelemahan atau kendala-kendala yang menyebabkan perusahaan sulit untuk berkembang atau meningkatkan kinerja perusahaannya. Kelemahan ini bisa jadi variabelnya sama dengan kekuatan yang dimiliki oleh perusahaan. Seperti tenaga kerja yang tidak terampil, tidak cukupnya modal usaha, kapasitas mesin tidak memadai dan sebagainya.

2. Analisis lingkungan eksternal

Analisis lingkungan ekternal adalah upaya untuk melakukan upaya identifikasi dan analisis terhadap berbagai faktor lingkungan luar seperti pengaruh perkembangan sosial, politik, ekonomi, ekologi, teknologi dan lain-lain yang mempunyai pengaruh terhadap kebijakan perusahaan. Analisis lingkungan eksternal pada dasarnya mencakup dua aspek, yaitu peluang (opportunity) dan ancaman (threat).

- Opportunity / peluang

Peluang merupakan kesempatan yang bagi perusahaan untuk berkembang. Peluang disini bisa tersedia di lingkungan. Variabel ini tidak bisa disediakan oleh perusahaan. Perusahaan hanya menyesuaikan diri dengan kesempatan yang muncul.

- Threat / Ancaman 
Variabel ini juga tidak dapat diciptakan oleh perusahaan. Ancaman ini pun juga tidak dapat dihilangkan, namun dapat diperkecil intensitasnya untuk muncul. Contoh kebijakan pemerintah pusat yang tidak konsisten, keterbatasan keuangan daerah, dan sebagainya.

Kunci sukses suatu perusahaan terutama terletak pada kemampuannya mengadaptasi dan beradaptasi dalam lingkungan yang selalu berubah. Cara dan saat yang tepat untuk bereaksi akan menentukan berhasil tidaknya perusahaan bertahan dan berkembang dalam lingkungan yang selalu berubah (Peng et al, 2008). Perubahan lingkungan yang terjadi selalu dengan mudah dapat kita amati sehari-hari. Gejala ketidakstabilan lingkungan, seperti globalisasi teknologi, tingginya tingkat inflasi, pengangguran, dan sebagainya.

\section{METODOLOGI PENELITIAN}

Penelitian ini menggunakan metode analisis kualitatif, dengan pengumpulan datanya berasal dari data primer yang didapatkan dari hasil wawancara dan observasi. Sedangkan untuk analisis data menggunakan analisis SWOT. Dalam analisis SWOT dijelaskan bahwa faktor penentu utama proses formulasi strategi adalah evaluasi atau identifikasi faktor-faktor eksternal dan internal. Lebih jauh lagi porter menekankan bahwa hal yang terpenting dalam pembentukan strategi keunggulan kompetitif adalah menghubungkan antara organisasi dengan lingkungannya. Dengan demikian pembentukan strategi harus dari analisis faktor-faktor internal dan eksternal.

Analisis SWOT ini akan sangat berguna untuk mengetahui seberapa besar faktor ekstern dan faktor intern akan mempengaruhi suatu organisasi. Analissi ini merupakan evaluasi untuk mengubah faktor negatif baik berasal dari Kelemahan (Weakness) dan Ancaman (Threath), lingkungan yang menjadi faktor-faktor positif yang berupa kekuatan (Strength) dan kesempatan (Opportunity). Setelah dilakukan identifikasi dan pemberian bobot dan rating faktor eksternal (peluang dan ancaman) serta faktor internal (kekuatan dan kelemahan), maka akan dapat diketahui posisi kredit pegawai BPR Bhakti Daya Ekonomi dalam diagram 
SWOT. Kemudian dari hasil analisis SWOT tersebut akan dapat diketahui matrik strategi yang akan menggambarkan faktor penghambat dan penentu keberhasilan BPR Bhakti Daya Ekonomi dalam melakukan strategi pemasaran untuk mampu bersaing dengan kompetitor terdekatnya khususnya BRI dan BPD. Untuk memberikan gambaran secara jelas tentang beberapa alternatif strategi dalam diagram SWOT dapat digambarkan sebagai berikut :

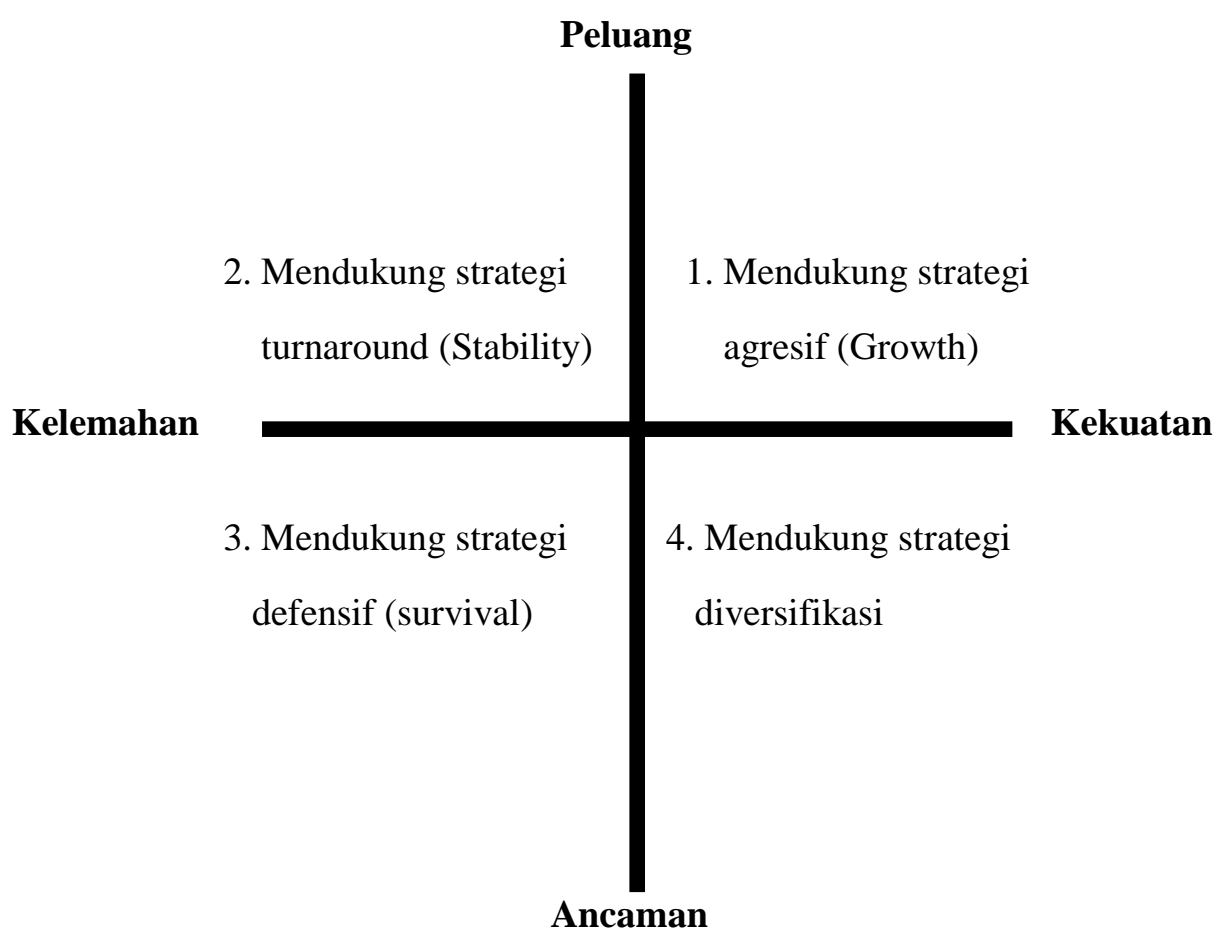

\section{Gambar 2 Diagram Analisis SWOT}

Penjelasannya sebagai berikut:

Kuadran 1: Merupakan situasi yang sangat menguntungkan, perusahaan memiliki peluang dan kekuatan sehingga dapat memanfaatkan peluang yang ada. Strategi yang harus diterapkan dalam kondisi ini adalah mendukung kebijakan pertumbuhan yang agresif.

Kuadran 2: Perusahaan menghadapi peluang pasar yang sangat besar, tetapi dilain pihak menghadapi beberapa kendala/ kelemahan internal. Fokus strategi perusahaan ini adalah meminimalkan masalah- 
masalah internal perusahaan sehingga dapat merebut peluang pasar yang lebih baik.

Kuadran 3: Pada kuadaran ini perusahaan dalam situasi yang sangat tidak menguntungkan, perusahaan tersebut menghadapi berbagai ancaman dan kelemahan internal.

Kuadran 4: Dalam menghadapi berbagai ancaman perusahaan masih memiliki kekuatan dari segi internal. Strategi yang harus dijalankan adalah menggunakan kekuatan untuk memanfaatkan peluang jangka panjang dengan cara strategi diversifikasi untuk produk dan pasar sasaran.

\section{HASIL DAN PEMBAHASAN}

Untuk merespon secara efektif perubahan dalam lingkungannya, maka BPR Bhakti Daya Ekonomi harus selalu mencermati lingkungan internal dan eksternalnya. Menurut Bryson (2011), mereka harus mengamati (Watch). Tetapi mereka juga harus menafsirkan apa yang dilihat. Dalam implementasi perencanaan strategis, adalah menyediakan informasi tentang kekuatan dan kelemahan internal organisasi sehubungan dengan peluang dan ancaman internal yang dihadapinya. Pendekatan bagi penilaian lingkungan eksternal dan internal bagi BPR Bhakti Daya Ekonomi akan menjadi wahana guna mengidentifikasi isuisu strategis, dan akan menyediakan informasi berharga bagi langkah selanjutnya. Isu strategi biasanya berkenaan dengan bagaimana organisasi (didalam) berhubungan dengan lingkungan lebih besar (di luar) di mana organisasi menjadi penghuni. Setiap strategi yang efektif akan mendapatkan keuntungan dari kekuatan dan peluang sekaligus meminimalkan atau mengatasi kelemahan dan ancaman.

Dari data primer yang telah terkumpul mengenai faktor eksternal (peluang dan ancaman), dan faktor internal (kekuatan dan kelemahan) yang ada di BPR Bhakti Daya Ekonomi, maka langkah selanjutnya adalah mencari nilai rata-rata tertimbang (Weight Score) dari faktor internal maupun faktor eksternal sebagai dasar untuk membentuk diagram SWOT. Dengan mengetahui besarnya nilai ratarata tertimbang dari faktor eksternal maupun faktor internal maka akan dapat 
diketahui pula posisi BPR Bhakti Daya Ekonomi dalam diagram SWOT. Diagram SWOT itu sendiri terdiri dari dua sumbu yaitu sumbu vertikal yang merupakan sumbu faktor eksternal (peluang dan ancaman), serta sumbu horisontal yang merupakan sumbu faktor internal (kekuatan dan kelemahan).

Besarnya nilai matrik strategi dapat diperoleh dengan mengalikan besarnya bobot dengan nilai rata-rata skor setiap variabel. Setelah bobot dan nilai rata-rata skor setiap variabel dikalikan, langkah selanjutnya adalah menjumlahkan seluruh nilai tertimbang yang terkandung dalam setiap variabel. Nilai total ini menunjukkan besarnya nilai matrik strategi internal dan matrik strategi eksternal yang sekaligus menunjukkan bagaimana jajaran manajemen BPR Bhakti Daya Ekonomi bereaksi terhadap faktor-faktor strategis baik internal maupun eksternalnya. Nilai total ini pulalah yang akan mengambarkan profil BPR Bhakti Daya Ekonomi dalam diagram SWOT dilihat dari peluang dan ancaman serta kekuatan dan kelemahan. Adapun hasilnya adalah sebagai berikut :

Tabel 2. Matrik Strategi Faktor Internal.

\begin{tabular}{|c|c|c|c|c|}
\hline No. & Faktor Kekuatan & Bobot & $\begin{array}{l}\text { Mean } \\
\text { Score }\end{array}$ & $\begin{array}{l}\text { Weight } \\
\text { Score }\end{array}$ \\
\hline 1 & $\begin{array}{l}\text { Nama BPR Bhakti Daya Ekonomi sudah dikenal luas pada } \\
\text { masyarakat DIY sehingga dapat /mampu mengangkat } \\
\text { produk kredit pegawai pada posisi yang baik }\end{array}$ & 0.031 & 3.800 & 0.118 \\
\hline 2 & $\begin{array}{l}\text { Nama BPR BDE yang dikenal sebagai "bank pelopor } \\
\text { pengentas kemiskinan" mampu mengangkat citra } \\
\text { dimasyarakat khususnya calon nasabah / nasabah kredit } \\
\text { pegawai. }\end{array}$ & 0.043 & 3.670 & 0.159 \\
\hline 3 & $\begin{array}{l}\text { Jenjang pendidikan formal yang dimiliki para karyawan BPR } \\
\text { Bhakti Daya Ekonomi dibanding bank BPD dan BRI. }\end{array}$ & 0.040 & 4.070 & 0.164 \\
\hline 4 & $\begin{array}{l}\text { Skill / keahlian yang dimiliki oleh karyawan BPR.Bhakti } \\
\text { Daya Ekonomi untuk menghadapi persaingan dibanding } \\
\text { bank BPD dan BRI. }\end{array}$ & 0.040 & 3.800 & 0.152 \\
\hline 5 & $\begin{array}{l}\text { Program pelatihan yang dilakukan untuk menghadapi } \\
\text { persaingan dibanding bank BPD dan BRI. }\end{array}$ & 0.030 & 4.130 & 0.125 \\
\hline 6 & $\begin{array}{l}\text { BPR BDE mempunyai strategi usaha yang berfungsi sebagai } \\
\text { pedoman umum yang memadai dalam mencapai misi/sasaran } \\
\text { umum yang berbeda dengan bank BRI dan BPD. }\end{array}$ & 0.050 & 3.930 & 0.195 \\
\hline 7 & $\begin{array}{l}\text { Bank mempunyai rencana jangka panjang } 5 \text { tahunan } \\
\text { (corporate plan) yang jelas dan sekurang-kurangnya } \\
\text { mencakup bidang permodalan, penghimpunan dana, } \\
\text { penyaluran dana, pengem-bangan produk dan sumber daya } \\
\text { manusia. }\end{array}$ & 0.036 & 4.070 & 0.147 \\
\hline 8 & $\begin{array}{l}\text { Pelaksanaan tugas dan pekerjaan didasarkan pada uraian } \\
\text { tugas pekerjaan (job description) yang tertulis secara spesifik }\end{array}$ & 0.036 & 4.270 & 0.154 \\
\hline
\end{tabular}


dan jelas.

9 Posisi-posisi strategis dijabat oleh orang-orang yang memiliki kualifikasi dengan persyaratan jabatan (job requirement) yang memadai.

10 Layanan yang berkaitan dengan kera-mahan dan hubungan interpersonal yang dilakukan oleh karyawan BPR Bhakti Daya Ekonomi terhadap para nasabahnya dibanding bank BPD dan BRI adalah sudah lebih baik.

11 Dibandingkan dengan BPD dan BRI, proses pencairan kredit pegawai pada BPR BDE adalah yang paling cepat.

12 Sistem birokrasi dan prosedur yang ada pada BPR Bhakti Daya Ekonomi adalah lebih mudah dan tidak berbelit-belit dibandingkan dengan bank BPD dan BRI.

13 Bagaimana faktor kemudahan dalam persyaratan untuk pengajuan kredit dibanding bank BPD dan BRI ?

14 Respon dari nasabah terhadap sistim jemput bola dan pelayanan langsung di rumah maupun di instansi dalam pelayanan kredit pegawai adalah lebih baik dibanding dengan bank BPD dan BRI.

15 Jangka waktu pinjaman maksimal (5 tahun) pada saat ini sudah mampu bersaing dengan bank BPD dan BRI.

16 Perhitungan perlunasan (perce-patan) pada saat ini sudah mampu bersaing dengan bank BPD dan BRI.

17 Sistim penyimpanan barang jaminan pada bank BDE apakah sudah memadai (jika dikaitkan dengan adanya kehilangan barang jaminan) dibanding bank BPD dan BRI.

18 Lokasi BPR Bhakti Daya Ekonomi yang berada di Pakem mendukung peningkatan jumlah nasabah yang ingin mengajukan permohonan kredit pegawai.

19 Jika BPR Bhakti Daya Ekonomi membuka cabang di Jogjakarta (Kodia atau mendekati Kodia), akan meningkatkan jumlah peminjam kredit pegawai.

\begin{tabular}{|c|c|c|}
\hline 0.035 & 3.800 & 0.134 \\
\hline 0.041 & 3.730 & 0.152 \\
\hline 0.034 & 4.130 & 0.141 \\
\hline 0.047 & 3.670 & 0.173 \\
\hline 0.031 & 3.870 & 0.120 \\
\hline 0.040 & 3.800 & 0.153 \\
\hline 0.046 & 4.130 & 0.189 \\
\hline 0.031 & 3.870 & 0.121 \\
\hline 0.040 & 4.200 & 0.168 \\
\hline 0.045 & 3.730 & 0.169 \\
\hline 0.035 & 4.070 & 0.143 \\
\hline
\end{tabular}

\begin{tabular}{llccc}
\hline No. & \multicolumn{1}{c}{ Faktor Kelemahan } & Bobot & $\begin{array}{c}\text { Mean } \\
\text { Score }\end{array}$ & $\begin{array}{c}\text { Weight } \\
\text { Score }\end{array}$ \\
1 & $\begin{array}{l}\text { Promosi baik melalui Iklan yang dilakukan oleh BPR Bhakti } \\
\text { Daya Ekonomi selama ini sudah memadai dibanding bank BPD } \\
\text { dan BR. }\end{array}$ & 0.035 & 2.330 & 0.082 \\
2 & $\begin{array}{l}\text { Promosi baik melalui brosur-brosur yang dilakukan oleh BPR } \\
\text { Bhakti Daya Ekonomi selama ini sudah memadai dibanding } \\
\text { bank BPD dan BRI. }\end{array}$ & 0.041 & 2.400 & 0.099 \\
$3 \quad \begin{array}{l}\text { Sumber daya manusia yang menangani pemasaran Kredit } \\
\text { Pegawai sudah memadai dibanding bank BPD dan BRI. }\end{array}$ & 0.044 & 2.200 & 0.097 \\
$4 \quad \begin{array}{l}\text { Bunga kredit pegawai yang ada pada saat ini mampu bersaing } \\
\text { dengan bank BPD dan BRI. }\end{array}$ & 0.034 & 2.270 & 0.077 \\
5 & $\begin{array}{l}\text { Plafond kredit yang diberikan pada saat ini sudah mampu } \\
\text { bersaing dengan bank BPD dan BRI. }\end{array}$ & 0.038 & 2.130 & 0.081 \\
6 & $\begin{array}{l}\text { Sistim pengadministrasian dengan komputer yang ada pada } \\
\text { BPR Bhakti Daya Ekonomi apakah sudah memadai dibanding } \\
\text { bank BPD dan BRI. }\end{array}$ & 0.038 & 2.400 & 0.092 \\
7 & $\begin{array}{l}\text { File nasabah yang ada baik dalam bentuk data elektronik } \\
\text { maupun datata secara manual keakuratan datanya sudah }\end{array}$ & 0.037 & 2.330 & 0.086 \\
\hline
\end{tabular}


memadai dibanding bank BPD dan BRI.

Sumber : Data Primer tahun 2015 (diolah)

Dari tabel 2 diatas dapat diketahui besarnya nilai matrik faktor kekuatan sebesar 2,878, yang berarti BPR Bhakti Daya Ekonomi mempunyai kekuatan yang sangat dominan jika dibandingkan dengan faktor kelemahannya dengan nilai matrik faktor kelemahan sebesar 0,611. Dengan menjumlah kedua nilai matrik faktor kekuatan dan matrik faktor kelemahan $(2,878+0,611)$ diperoleh nilai matrik strategi faktor internal. Nilai inilah yang kemudian akan menggambarkan profil BPR Bhakti Daya Ekonomi dalam diagram SWOT sumbu horisontal.

Tabel 3. Matrik Strategi Faktor Ekstenal

\begin{tabular}{|c|c|c|c|c|}
\hline No & Variabel Peluang & Bobot & $\begin{array}{l}\text { Mean } \\
\text { Score }\end{array}$ & $\begin{array}{l}\text { Weight } \\
\text { Score }\end{array}$ \\
\hline 1 & $\begin{array}{l}\text { Diberlakukannya penyesuaian terhadap tunjangan yang } \\
\text { diterima akan berpengaruh positif terhadap produk kredit } \\
\text { pegawai. }\end{array}$ & 0.095 & 4.063 & 0.386 \\
\hline 2 & $\begin{array}{l}\text { Peraturan yang dikeluarkan oleh pemerintah (menteri } \\
\text { keuangan RI dan Bank Indonesia) dalam bentuk SK dan SE } \\
\text { tentang penetapan CAR minimum untuk BPR } \\
\text { mempengaruhi kredit pegawai secara positif. }\end{array}$ & 0.098 & 3.614 & 0.354 \\
\hline 3 & $\begin{array}{l}\text { Peraturan yang dikeluarkan oleh pemerintah (menteri } \\
\text { keuangan RI dan Bank Indonesia) dalam bentuk SK dan SE } \\
\text { tentang penetapan BMPK maksimal untuk BPR } \\
\text { mempengaruhi kredit pegawai secara positif. }\end{array}$ & 0.067 & 3.764 & 0.252 \\
\hline 4 & $\begin{array}{l}\text { Peraturan yang dikeluarkan oleh pemerintah (menteri } \\
\text { keuangan RI dan Bank Indonesia) dalam bentuk SK dan SE } \\
\text { tentang penetapan LDR untuk BPR mempengaruhi kredit } \\
\text { pegawai secara positif. }\end{array}$ & 0.045 & 3.937 & 0.177 \\
\hline \multicolumn{2}{|r|}{ Nilai Faktor Peluang } & & & 1.169 \\
\hline No & Variabel Ancaman & & & \\
\hline 1 & $\begin{array}{l}\text { Dengan adanya kebijakan untuk gaji PNS melalui bank BPD } \\
\text { berpengaruh positif terhadap perkembangan kredit pegawai } \\
\text { bagi BPR BDE. }\end{array}$ & 0.071 & 1.819 & 0.129 \\
\hline 2 & $\begin{array}{l}\text { Dengan adanya perampingan instansi (penggabungan) } \\
\text { berpengaruh positif terhadap produk kredit pegawai. }\end{array}$ & 0.093 & 1.976 & 0.184 \\
\hline 3 & $\begin{array}{l}\text { Dengan adanya kebijakan pemerintah dengan menaikkan } \\
\text { gaji pegawai akan berpengaruh positif terhadap produk } \\
\text { kredit pegawai. }\end{array}$ & 0.105 & 2.134 & 0.224 \\
\hline 4 & $\begin{array}{l}\text { Dengan adanya penyesuaian terhadap tunjangan yang } \\
\text { diterima akan berpengaruh positif terhadap produk kredit } \\
\text { pegawai. }\end{array}$ & 0.044 & 2.567 & 0.113 \\
\hline 5 & BPR BDE dalam hal penggunaan teknologi informasi lebih & 0.109 & 2.134 & 0.233 \\
\hline
\end{tabular}




\begin{tabular}{|c|c|c|c|c|}
\hline & $\begin{array}{l}\text { unggul dibandingkan dengan BRI dan BPD yang ada di } \\
\text { wilayah Pakem. }\end{array}$ & & & \\
\hline 6 & $\begin{array}{l}\text { Dengan hadirnya teknologi informasi dan penerapan } \\
\text { international banking oleh BRI dan BPD tidak berpengaruh } \\
\text { terhadap pengembangan kredit pegawai bagi BPR BDE. }\end{array}$ & 0.046 & 2.299 & 0.106 \\
\hline 7 & $\begin{array}{l}\text { Apakah faktor keamanan nasional (seperti banyaknya } \\
\text { ancaman bom) akan berpengaruh positif secara langsung } \\
\text { atau tidak langsung terhadap perkembang-an kredit pegawai } \\
\text { ? }\end{array}$ & 0.036 & 2.362 & 0.085 \\
\hline 8 & $\begin{array}{l}\text { Apakah faktor keamanan dalam skala regional (seperti } \\
\text { adanya huru hara \& penodongan ) akan berpengaruh positif } \\
\text { secara langsung atau tidak langsung terhadap perkembangan } \\
\text { kredit pegawai? }\end{array}$ & 0.073 & 2.252 & 0.164 \\
\hline 9 & $\begin{array}{l}\text { Dengan adanya ekspansi Bank BPD Cab. Sleman dan BRI } \\
\text { Cab. Sleman di bisnis retail banking tidak akan mengancam } \\
\text { pangsa pasar kredit pegawai khususnya calon nasabah baru } \\
\text { karena BDE merupakan penguasa market di Wilayah Pakem. }\end{array}$ & 0.065 & 1.992 & 0.129 \\
\hline 10 & $\begin{array}{l}\text { Dengan adanya promosi yang gencar dari bank BPD dan } \\
\text { BRI di media cetak maupun elektronik, tidak akan } \\
\text { berpengaruh negatif terhadap BPR Bhakti Daya Ekonomi } \\
\text { khususnya untuk produk kredit pegawai }\end{array}$ & 0.052 & 2.441 & 0.127 \\
\hline \multicolumn{4}{|c|}{ Nilai Faktor Ancaman } & 1.495 \\
\hline \multicolumn{4}{|c|}{ Matrik Strategi Faktor Eksternal (External Strategic Factors Analysis) } & 2.664 \\
\hline
\end{tabular}

Dari tabel 3 dapat diketahui besarnya nilai matrik faktor peluang sebesar 1,169 dan nilai matrik faktor ancaman sebesar 1,495. Dengan melihat kedua nilai matrik faktor tersebut dapat diketahui bahwa faktor ancaman eksternal BPR Bhakti Daya Ekonomi sedikit lebih dominan jika dibandingkan dengan faktor peluangnya. Dengan menjumlah kedua nilai matrik faktor peluang dan ancaman $(1,169+1,495)$ diperoleh nilai titik matrik strategi faktor eksternal sebesar 2,664. Nilai inilah yang kemudian akan menggambarkan profil BPR Bhakti Daya Ekonomi dalam diagram SWOT sumbu vertikal.

Selanjutnya dengan menggunakan faktor strategis (eksternal dan internal) sebagaimana telah dijelaskan dalam tabel 2 untuk faktor internal dan tabel 3 untuk faktor eksternal, maka dapat disusun Matrik SWOT yang akan menggambarkan posisi BPR Bhakti Dhaya Ekonomi dalam diagram SWOT yang dapat digunakan sebagai dasar untuk menyusun strategi pemasaran BPR Bhakti Daya Ekonomi dengan memanfaatkan segenap kekuatan dan peluang yang ada untuk mengeliminasi kelemahan dan tingginya ancaman dari lingkungan ekternal. 


\section{Faktor Srategi Internal}

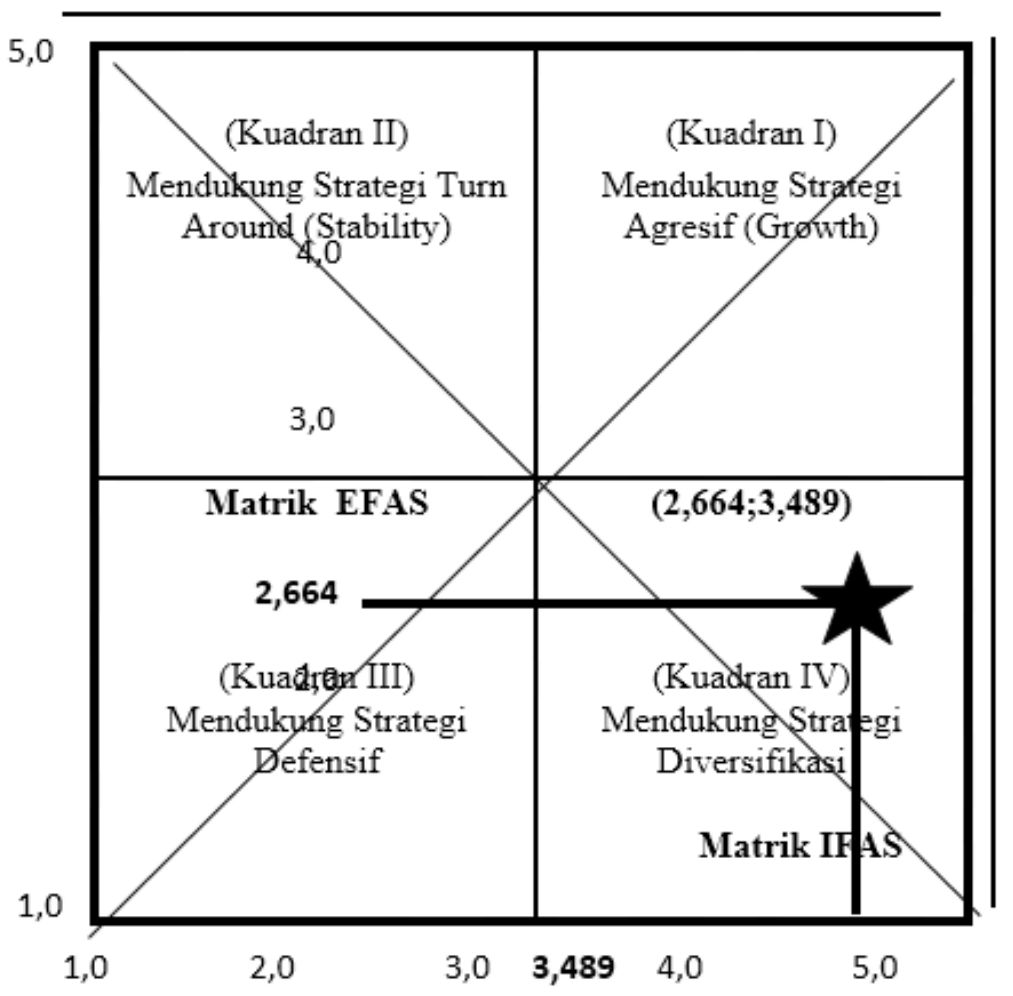

Gambar 2. Matrik SWOT

Dari analisis faktor strategik internal (IFAS) dan analisis faktor strategi eksternal (EFAS) dapat diketahui besarnya nilai titik matrik sebesar 2,664 (titik matrik EFAS) dan 3,489 (titik matrik IFAS). Setelah memplotkan titik matrik faktor internal dan faktor eksternal kedalam diagram SWOT dapat diketahui bahwa strategi pemasaran yang paling sesuai bagi BPR Bhakti Daya Ekonomi dalam menghadapi persaingan adalah dengan menggunakan strategi SW (Strength \& Weaknesses), artinya BPR Bhakti Daya Ekonomi berkesempatan untuk menggunakan kekuatan-kekuatan internal yang dimiliki untuk meminimalisasi ancaman yang dihadapi.

Berdasarkan hasil analisis SWOT dapat diketahui bahwa posisi BPR Bhakti Daya Ekonomi adalah berada dalam kuadran IV. Pada kuadran ini Bank berada pada posisi dimana kekuatan internalnya relatif lebih dominan dibandingkan dengan kelemahannya. Akan tetapi dalam menghadapi lingkungan eksternalnya, ancaman yang dihadapi relatif lebih besar dibandingkan dengan 
peluangnya. Hal ini berarti BPR Bhakti Daya Ekonomi mempunyai kemampuan intern yang lebih baik untuk mengembangkan usahanya terutama dengan memanfaatkan kelebihan yang dipunyai, maka strategi dasar yang tepat dalam situasi seperti ini yaitu melakukan konsolidasi untuk mengatasi ancaman yang dihadapi, dengan melakukan diversifikasi usaha sesuai dengan kemampuan yang ada. Besar atau kecilnya usaha konsolidasi intern ini tergantung pada besar atau kecilnya keunggulan intern dibandingkan dengan kelemahannya. Makin besar keunggulannya, maka usaha konsolidasi relatif sedikit. Sebaliknya makin sedikit perbedaan keunggulan dengan kelemahan intern bank, usaha konsolidasinya harus semakin besar.

Dari hasil analisis SWOT terlihat bahwa poisisi BPR Bhakti Daya ekonomi berada pada area dibawah garis bagi. Pada area ini berarti kekuatan Bank relatif lebih besar dibandingkan dengan kelemahannya, dipihak lain, ancaman dari lingkungan eksternalnya relatif lebih besar daripada peluang yang dimiliki, maka strategi yang paling tepat untuk kondisi seperti ini adalah melakukan strategi diversifikasi yang konsentrik, artinya dalam menjalankan strategi diversifikasi ini, bank perlu melakukan pilihan yang selektif dalam mendiversifikasi jenis produk kredit pegawai atau memanfaatkan peluang pasar yang benar-benar disesuaikan dengan kelebihan kekuatan internalnya. Sehingga bisa juga dikatakan bahwa dalam menjalankan diversifikasinya, bank berkonsentrasi pada pasar tertentu yang potensial dengan melakukan terobosan-terobosan baru disektor kredit yang berkaitan dengan karyawan/ pegawai yang merupakan nasabahnya. Kalau selama ini produk kredit pegawai hanya diperuntukkan kepada Pegawai Negeri Sipil dan TNI / POLRI, maka BPR Bhakti Daya Ekonomi hendaknya mulai melirik dengan membuka layanan Kredit Pegawai Swasta yang merupakan pasar sekaligus produk baru bagi BPR.Bhakti Daya Ekonomi dimana merupakan sebuah peluang yang selama ini belum digarap.

Dengan adanya kebijakan pemerintah propinsi Daerah Istimewa Yogyakarta yang melakukan penyaluran gaji melalui Bank Pembangunan Daerah tentunya akan menjadi ancaman yang sangat serius bagi BPR Bhakti Daya Ekonomi, karena dengan adanya kebijakan tersebut tidak menutup kemungkinan 
terjalinnya ikatan emosional dari para pegawai negeri terhadap Bank Pembangunan Daerah yang akan membawa sinergi yang sangat positif terhadap pelayanan kredit pegawai negeri yang sudah jelas-jelas didepan mata. Kebijakan pemerintah tersebut tentunya akan sangat merugikan kepada BPR Bhakti Daya Ekonomi yang selama ini pendapatan kreditnya masih sangat tergantung dari produk kredit pegawai. Kondisi tersebut pada saat ini memang belum terasa signifikan dampaknya, akan tetapi dalam jangka waktu yang tidak akan lama lagi pasti dampak kebijakan tersebut akan mulai terasa. Dengan kebijakan pemerintah tersebut menjadikan Bank Pembangunan Daerah mampu memberikan pelayanan "One Stop Service" sehingga akan lebih efisien dan bisa menghemat operational cost, sehingga BPD bisa menekan biaya bunga terhadap kredit pegawainya. Kondisi tersebut tentunya akan semakin mempersulit posisi BPR Bhakti Daya Ekonomi karena kelemahan internal yang selama ini menjadi penghambat kemajuan kredit pegawai adalah terletak pada biaya bunga yang terlalu tinggi dibandingkan dengan BPD dan BRI.

Melihat kenyataan diatas maka BPR Bhakti Daya Ekonomi harus berani melakukan terobosan baru untuk segera melepaskan diri dari ketergantunganya terhadap produk kredit pegawai khususnya pegawai negeri sipil dan TNI/POLRI dengan menggarap segmen baru yang lebih potensial yaitu produk kredit pegawai swasta. Berdasarkan data dari Pusat Antar Universitas (PAU) bekerja sama dengan Bank Indonesia memberikan catatan bahwa usaha kecil mendominasi kegiatan perekonomian daerah dengan jumlah sekitar 140 ribuan dan sekitar 6000 perusahaan yang memiliki SIUP, mereka itu merupakan potensial market bagi BPR Bhakti Daya Ekonomi. Bank-bank umum dengan sistem birokrasi mulai dari jaminan, proses dan aturan pemerintah yang harus dilakukan oleh manajemen bank merupakan kelemahan internal bank umum yang dapat dimanfaatkan oleh BPR Bhakti Daya Ekonomi. Jadi disini nampak perbedaan yang sangat signifikan dari perbankan umum dan BPR yang bergerak di sektor riil didalam melakukan bisnisnya. Bank-bank umum menjalankan bisnisnya dengan konsep "Bisnis mengikuti birokrasi" sedang sebaliknya BPR yang bergerak di sektor riil menggunakan konsep "Birokrasi mengikuti bisnis". 


\section{DAFTAR PUSTAKA}

Bryson, J. M. (2011). Strategic planning for public and nonprofit organizations: A guide to strengthening and sustaining organizational achievement (Vol. 1). John Wiley \& Sons.

David, F. R. (2011). Strategic management: Concepts and cases. Peaeson/Prentice Hall.

Peng, M. W., Wang, D. Y., \& Jiang, Y. (2008). An institution-based view of international business strategy: A focus on emerging economies. Journal of international business studies, 39(5), 920-936.

Pfeffer, J., \& Salancik, G. R. (2003). The external control of organizations: A resource dependence perspective. Stanford University Press.

Porter, M. E. (2008). Competitive strategy: Techniques for analyzing industries and competitors. Simon and Schuster.

Rangkuti, F. (2002). Analisis SWOT teknik membedah kasus bisnis. Gramedia Pustaka Utama.

Singh, D., \& Kohli, G. (2006). Evaluation of private sector banks in India: A SWOT analysis. Journal of Management Research, 6(2), 84.

Thompson, A. A., \& Strickland, A. J. (2007). Strategic management: Concepts and cases. McGraw-Hill/Irvin 